Saudi Journal of Medical and Pharmaceutical Sciences

Abbreviated Key Title: Saudi J Med Pharm Sci ISSN 2413-4929 (Print) |ISSN 2413-4910 (Online) Scholars Middle East Publishers, Dubai, United Arab Emirates Journal homepage: https://saudijournals.com/sjmps

\title{
Quality Control of a Boldo Tisanes Brand Commercialized in Costa Rica Following the Central American Technical Regulation for Natural Products
}

\author{
Gamboa Camacho Stefanny ${ }^{1}$, González Vargas Omar $^{1}$, Guevara Saborío Gloriana ${ }^{1}$, Murillo Castillo Brayan ${ }^{1}$, Loría \\ Gutiérrez Arlene $^{2}$, Blanco Barrantes Jeimy ${ }^{3}$, Mora Román Juan José ${ }^{4 *}$ \\ ${ }^{1}$ Pharmacy student, Faculty of Pharmacy, Universidad de Costa Rica, San José, Costa Rica \\ ${ }^{2}$ Pharmacology, Toxicology and Pharmacodependence Department, Faculty of Pharmacy, Universidad de Costa Rica, San José, Costa Rica \\ ${ }^{3}$ Laboratory of Pharmaceutical Analysis and Assessment (LAYAFA), Universidad de Costa Rica, San José, Costa Rica \\ ${ }^{4}$ Industrial Pharmacy Department, Faculty of Pharmacy, Universidad de Costa Rica, San José, Costa Rica
}

DOI: $10.36348 /$ sjmps.2020.v06i01.019 $\quad$ | Received: 20.01.2020 | Accepted: 27.01.2020 | Published: 30.01 .2020

*Corresponding author: Mora Román Juan José

\section{Abstract}

One of the medicinal species used as raw material for the tisanes preparation is the boldo leaf (Peumus boldus). This plant is commonly used as treatment for a variety of conditions, such as digestive and hepatobiliary disorders. It is traditionally known for its choleretic, cholagogue, diuretic, and digestive properties, among others. The objectives of this work were to evaluate the quality of four batches of boldo tisanes of a brand commercialized in Costa Rica through various physicochemical and microbiological tests established in the Central American Technical Regulation (RTCA) 11.03.56.09, and to identify the reproducibility of the quality parameters for the four batches employed. For this reason, the following tests were done: labeling, organoleptic characteristics, foreign matter determination, minimum fill, lead limit, arsenic limit, loss on drying, total ash, microbial enumeration, and specific microorganisms (E. coli and Salmonella sp). The four analyzed batches were in compliance for all assays, except the labeling test, since in all cases only 2 of the 4 items established for the primary packaging (batch number and expiration date) and 3 of the 19 items indicated for the secondary packaging (qualitative-quantitative composition, interactions, and adverse effects) were not found. In addition, the batch 2 had a browner color compared to the others, not complying with the organoleptic test specifications, specifically the color. This is reaffirmed by obtaining a greater percentage of branches in its composition during the foreign matter test. For these reasons, greater controls must be made on the raw material used for the product preparation to achieve reproducibility between the quality characteristics required for the different batches.

Keywords: natural product, tisane, boldo, quality control, Central American Technical Regulation.

Copyright @ 2020: This is an open-access article distributed under the terms of the Creative Commons Attribution license which permits unrestricted use, distribution, and reproduction in any medium for non-commercial use (NonCommercial, or CC-BY-NC) provided the original author and source are credited.

\section{INTRODUCTION}

The nature is a rich source of physical and chemical varieties [1]. Herbal medicines and their derivatives have been incorporated into traditional medicine since the history beginning [2] and have been used by the world's population majority for thousands of years [3]. However, it is until recent times that the increasingly expanded use of medicinal plants has begun to gain acceptance worldwide [2]. For example, more than 1,300 medicinal plants are used in Europe, of which $90 \%$ are harvested from wild resources, and in the United States, about 118 of the 150 prescription drugs are based on natural sources [4]. In addition, more than $80 \%$ of people in developing countries are totally dependent on medicinal plants as their primary treatment $[2,4,5]$. Studies in Latin America report that medicinal plants are widely used. For example, in Cordoba, Argentina, $100 \%$ of the population knew about the use of medicinal plants, while in Brazil, the use frequency varies between 70 and $98 \%$ of the total population, depending on the area. In Panama, $84 \%$ of the people who went to a primary care unit employed them [6].

One of the pharmaceutical dosage forms for these products is the tisane. Herbal teas should be called as tisanes or infusions. However, they are usually referred as herbal teas by consumers and researchers [7]. The raw material used may consist of fresh or dried leaves, fruits, flowers, pollen, nuts, barks, seeds, and roots of one or several species [8]. 
These products are usually consumed for their physical or medicinal effects, especially stimulant, relaxing, or sedative properties $[9,10]$. Its popularity is due to the high availability of herbal teas and medicinal plants formulations, the low price, the virtual absence of adverse effects and biological aggressiveness, and recently, the tendency to replace or complement conventional medicines and drugs [11].

One of the medicinal species used as raw material for the tisanes preparation is the boldo leaf (Peumus boldus). It belongs to the Monimiaceae family and is native of Chile. It grows in areas that have a microclimate with conditions similar to the Mediterranean sector. It can also be found in areas of Ecuador, Bolivia, Argentina, and Peru, as well as acclimated areas in Morocco and North Africa [12]. It is commonly used as infusions, tinctures, or extract for the treatment of diverse conditions [13]. It is traditionally known for its choleretic, cholagogue, diuretic, and digestive properties, among others [14]. Also, the antioxidant activity of its main active principle, boldine, has been determined [15].

In Costa Rica, tisanes are commercialized as natural products. Yet, as with medicines, and due to their pharmacological properties, it is important to evaluate their quality, safety, and efficacy in order to protect the Costa Rican population that consumes these products [16]. Besides, this control is important, since different factors can affect the qualitative and quantitative chemical profile of natural raw materials, such as the geographical origin (climate, soil, photoperiod), the genotype, the plant part used (leaves, stems, root, bark), the time (year, season, time of day), and the harvest, storage, processing, and extraction conditions. All this confirmed that an adequate control is necessary [17]. In fact, the variable content in different batches of the same product may contribute to its negative effects [18].

Previous works related to these products have been carried out for valerian [19], senna leaf [20], and peppermint [21]. Though, this information can not be extrapolated to others, because each raw material is unique. For this reason, the objectives of this work were to evaluate the quality of four batches of boldo tisanes of a brand commercialized in Costa Rica through various physicochemical and microbiological tests established in the Central American Technical Regulation (RTCA) 11.03.56.09 [22], and to identify the reproducibility of the quality parameters for the four batches used.

\section{Materials AND Methods Product Sampling and Procedures Selection}

Four batches of a boldo tisanes brand were purchased in different supermarkets in the Greater
Metropolitan Area of Costa Rica. The batches were identified as 1, 2, 3, and 4.

For the procedures selection of the physicochemical and microbiological tests done, the official books established by the RTCA 11.03.56.09 [22] were used.

\section{Labeling Test}

The 4 items stipulated for the primary packaging and the 19 indicated for the secondary packaging were reviewed, according to the RTCA 11.03.56.09 [22]. It was indicated that the labeling of a natural product must be in compliance with the RTCA 11.04.41:06 [23].

\section{Organoleptic characteristics test}

The organoleptic characteristics of odor, color, and texture were analyzed. For this, 10 tisanes were used, as established by the British Pharmacopoeia (BP) 2013 [24]. The inspection was carried out with a Konus ${ }^{\circledR}$ luminous lens. The product was considered in compliance by having a characteristic odor (especially when rubbed), a grayish-green color, and a soft texture.

\section{Foreign matter determination test}

The test was done according to the procedure indicated in the BP 2013 [24]. For this, 10 tisanes were opened. Their contents were dispersed on a white surface and observed with the help of a Konus ${ }^{\circledR}$ luminous magnifying glass. The foreign matter found was separated and weighed on an Adam ${ }^{\circledR}$ PW254 analytical balance. The foreign matter percentage was determined with respect to the total sample weight. The product was in compliance if the branches percentage was less than $4 \%$ and that of foreign elements did not exceed $2 \%$.

\section{Minimum fill test}

It was carried out according to the procedure indicated in the general chapter $\langle 755\rangle$ of the United States Pharmacopeia (USP) 40 [25]. To do this, 10 tisanes were taken from each boldo tisanes batch. Then, they were cut to open and carefully extract the content, so that no sample was lost in the process. In an Adam ${ }^{\circledR}$ PW254 analytical balance, the individual content of each tisane was weighed and the value recorded. The product was considered to be in compliance if the net content of any individual tisane was not less than $90 \%$ of the declared amount.

\section{Lead limit test}

The evaluation of heavy metals was made for the lead element according to the procedure described for method A of the <2.4.8> chapter of the European Pharmacopoeia 5.0 [26].

For the sample, two tisanes were taken in a $100 \mathrm{ml}$ beaker and $22 \mathrm{ml}$ of distilled water were added. 
It was left to rest for 5 minutes. After this, the tisanes were extracted by compressing them, depositing the extracted liquid in the same beaker. Then, an aliquot of $12.0 \mathrm{ml}$ was taken for the sample, $2.0 \mathrm{ml}$ for the standard and $2.0 \mathrm{ml}$ for the blank. Each one was put in a different test tube. $10 \mathrm{ml}$ of the lead standard (1 ppm) and $10 \mathrm{ml}$ of distilled water were added to the standard tube and the blank tube, respectively. Next, $2 \mathrm{ml}$ of acetic acid-sodium acetate buffer at a $3.5 \mathrm{pH}, 0.5 \mathrm{ml}$ of diluted acetic acid, and $1.2 \mathrm{ml}$ of thioacetamide solution (previously heated in a steam bath) were added to each tube. The result was consistent if both the blank and the sample had a brown color of less intensity than the standard.

\section{Arsenic Limit Test}

The test was carried out according to the procedure described for method A of the <2.4.2> chapter of the European Pharmacopoeia 5.0 [26].

In a $100 \mathrm{ml}$ beaker, one tisane was placed and $11 \mathrm{ml}$ of distilled water were added. It was left to rest for 5 minutes. After this, the tisane was extracted by compressing it and the extracted liquid was deposited in the same beaker. Later, an aliquot of $10.0 \mathrm{ml}$ was taken and deposited in a conical flask. Then, $15 \mathrm{ml}$ of $12 \mathrm{M}$ $\mathrm{HCl}, 0.1 \mathrm{ml}$ of stannous chloride and $5 \mathrm{ml}$ of $16 \% \mathrm{w} / \mathrm{v}$ potassium iodide were added. It was left to stand for 15 minutes. After that, $3 \mathrm{~g}$ of zinc chips were added. Next, the two parts of the apparatus were assembled and the flask was placed in a water bath with a temperature range between 90 and $100{ }^{\circ} \mathrm{C}$. The standard was prepared in the same way, using $1 \mathrm{ml}$ of standard arsenic solution $(1 \mathrm{ppm})$. After not less than 2 hours, the stain produced on the mercury bromide paper in the sample should not be more intense than that of the reference standard.

\section{Loss on Drying Test}

It was done according to the general chapter $<731>$ description of the USP 40 [25]. First, a crucible was dried for 30 minutes at $105{ }^{\circ} \mathrm{C}$ in a Thermo Scientific ${ }^{\circledR}$ HeraTherm oven stove, and the process was repeated until constant weight. Next, the content of a boldo tisane was weighed on an Adam ${ }^{\circledR}$ PW254 analytical balance, placed in the crucible and accurately weighed together with its content. Subsequently, it was placed in the oven and dried for two hours at $105{ }^{\circ} \mathrm{C}$. After cooling in a desiccator, it was weighed again in the analytical balance to calculate the loss percentage. These periods of heating and cooling were continued until reaching a constant weight.

\section{Total ash test}

To carry out this test, the procedure described in the general chapter $<561\rangle$ of the USP 40 was made [25]. The content of two boldo tisanes was accurately weighed on an Adam ${ }^{\circledR}$ PW254 analytical balance in a crucible taken previously to constant weight. It was incised gently at the beginning and then the temperature was gradually increasing to $675^{\circ} \mathrm{C}$. The procedure was done for two hours. Finally, the ash obtained was cooled in a desiccator and weighed in the analytical balance to calculate the total ash percentage. These periods of heating and cooling were continued until reaching a constant weight. The compliant sample was considered if the total ash was less than $13.0 \%$ with respect to the initial weight.

\section{Microbial Enumeration Tests}

The tests were carried out according to the procedure described in the general chapter $\langle 61\rangle$ of the USP 40 [25].

$10 \mathrm{~g}$ of the product to be analyzed were taken and added in $100 \mathrm{ml}$ of Bacto ${ }^{\mathrm{TM}}$ casein-soybean digest broth. Next, two Petri dishes were prepared for each medium at the required dilution level. The plates with Bacto $^{\mathrm{TM}}$ casein-soybean digest agar were used for the total aerobic microbial count. They were incubated at $33{ }^{\circ} \mathrm{C}$ for 48 hours. In the case of yeasts and molds count, Liofilchem ${ }^{\text {TM }}$ potato dextrose agar was employed. Then, the plates were incubated at $22.5{ }^{\circ} \mathrm{C}$ for five days. After that, the enumeration arithmetic mean of each medium was taken and the number of colony forming units (cfu) was calculated per $\mathrm{g}$ of product. According to the RTCA 11.03.56.09, the total aerobic microbial count should not exceed $10^{7} \mathrm{cfu} / \mathrm{g}$, while the total combined yeasts and molds count should not exceed $10^{5} \mathrm{cfu} / \mathrm{g}$ [22].

\section{Microorganisms' specific tests}

The procedures of chapter $<2022>$ of USP 40 were followed [25].

\section{Escherichia coli absence test}

$10 \mathrm{~g}$ of the product to be analyzed were added in $100 \mathrm{ml}$ of Bacto ${ }^{\mathrm{TM}}$ casein-soybean digest broth. Next, the sample was incubated at a temperature of 33 ${ }^{\circ} \mathrm{C}$ for 24 hours. Then, a $1.0 \mathrm{ml}$ aliquot of the sample was pipetted into a container with Difco ${ }^{\mathrm{TM}}$ MacConkey broth. Later, was mixed and incubated at $44{ }^{\circ} \mathrm{C}$ for 48 hours. After this period, two samples, each of $1.00 \mathrm{ml}$ of the broth, were taken to inoculate two $\mathrm{BBL}^{\mathrm{TM}}$ MacConkey agar plates. Plates were incubated at $33{ }^{\circ} \mathrm{C}$ for 24 hours. At the end, the inoculated plates were examined.

\section{Salmonella sp absence test}

From the sample prepared for the E. coli absence test, a $1.00 \mathrm{ml}$ aliquot was taken and added to $10 \mathrm{ml}$ of Difco ${ }^{\mathrm{TM}}$ Rappaport Vassiliadis Salmonella enrichment broth. The solution was mixed and incubated at $33{ }^{\circ} \mathrm{C}$ for 24 hours. Afterward, two samples were taken, each of $1.00 \mathrm{ml}$ of the solution, to inoculate two plates of Difco $^{\mathrm{TM}}$ xylose lysine deoxycholate agar. These were incubated at $33{ }^{\circ} \mathrm{C}$ for 24 hours. 
Both tests were in compliance if there was absence of both pathogenic microorganisms when examining the plates.

\section{RESUlTS AND DISCUSSION}

The quality control of natural products with pharmacological properties is necessary to ensure that they do not cause adverse effects or even endanger the consumers' lives, who often consider them to be completely safe products, due to their origin [27]. First, the information required in the primary and secondary product packaging of the product was evaluated, which is necessary to reduce the incorrect consumption errors caused by inappropriate labeling (Table 1) [28].

Table-1: Results of the labeling test of the primary and secondary packaging for four batches of a boldo tisanes brand commercialized in Costa Rica

\begin{tabular}{|c|c|c|c|c|}
\hline \multirow[t]{2}{*}{ Required information } & \multicolumn{4}{|c|}{ Fulfillment } \\
\hline & Batch 1 & Batch 2 & Batch 3 & Batch 4 \\
\hline \multicolumn{5}{|l|}{ Primary packaging } \\
\hline Brand name & Yes & Yes & Yes & Yes \\
\hline Batch number & No & No & No & No \\
\hline Expiration date & No & No & No & No \\
\hline Manufacturer laboratory name or logo & Yes & Yes & Yes & Yes \\
\hline \multicolumn{5}{|l|}{ Secondary packaging } \\
\hline Product name & Yes & Yes & Yes & Yes \\
\hline Pharmaceutical form & Yes & Yes & Yes & Yes \\
\hline Indications & Yes & Yes & Yes & Yes \\
\hline Employment form & Yes & Yes & Yes & Yes \\
\hline Quali-quantitative composition of active ingredients & No & $\mathrm{No}$ & $\mathrm{No}$ & $\mathrm{No}$ \\
\hline Registration number & Yes & Yes & Yes & Yes \\
\hline Manufacturer name and country of origin & Yes & Yes & Yes & Yes \\
\hline Net amount of the finished product & Yes & Yes & Yes & Yes \\
\hline Batch number & Yes & Yes & Yes & Yes \\
\hline Storage conditions & Yes & Yes & Yes & Yes \\
\hline Expiration date & Yes & Yes & Yes & Yes \\
\hline Contraindications and warnings & Yes & Yes & Yes & Yes \\
\hline Interactions & No & No & No & No \\
\hline Side effects & No & No & No & No \\
\hline General labeling & Yes & Yes & Yes & Yes \\
\hline Special labeling & Yes & Yes & Yes & Yes \\
\hline Posology & Yes & Yes & Yes & Yes \\
\hline Administration route & Yes & Yes & Yes & Yes \\
\hline $\begin{array}{l}\text { Use during pregnancy, breastfeeding, elderly, and } \\
\text { children under } 2 \text { years }\end{array}$ & Yes & Yes & Yes & Yes \\
\hline
\end{tabular}

As for the primary packaging, the data referring to the product and the manufacturing company names were present. However, no information was found regarding the batch number. The presence of this is essential to follow a product, especially in a complaint case and if a market withdrawal is necessary [29]. Another detail not shown is the expiration date. It provides information related to the time over which the drug potency and integrity in its sealed container remain intact. Providing this is necessary, because it brings information about the extent to which the manufacturing company would guarantee the product safety, full potency, and stability [30].

Regarding the review of the secondary packaging in which these tisanes are commercialized, there was compliance with 16 of the 19 aspects requested by the RTCA 11.04.41:06 [23]. The items not found were the qualitative and quantitative information, as well as the interactions and the adverse effects of boldo consumption. Data about the formulation components and their respective quantities is required, so that each person is aware of what they are consuming. In the case of boldo leaves, it has been reported to contain $1.2 \%$ of tannins and 2 to $3 \%$ of essential oils (up to $45 \%$ of ascaridole, $30 \%$ of cineole, and at least 22 other identified constituents, mainly terpenoids). In addition, dried leaves of Peumus boldus have been reported to contain alkaloids in the 0.25 to $0.54 \%$ or 0.4 to $0.5 \%$ range $[13,31]$, of which approximately 12 to $19 \%$ is boldine [31-33]. This alkaloid effect has been associated with an antagonism on human 5-HT3 receptors [33].

Regarding the boldo interactions identified, the European Medicines Agency (EMA) indicates that the information is limited and reports a case about the tacrolimus levels decrease due to a potential interaction 
with a boldo preparation [34]. However, information was found regarding interactions with the following drugs: lithium, hepatotoxic drugs (acetaminophen, amiodarone, carbamazepine, isoniazid, methotrexate, methyldopa, fluconazole, itraconazole, erythromycin, phenytoin, lovastatin, pravastatin, simvastatin), anticoagulants, and antiplatelet agents (aspirin, clopidogrel, diclofenac, ibuprofen, naproxen, dalteparin, enoxaparin, heparin, warfarin) $[35,36]$.

As a complement, the adverse effects information, also absent, indicates that it can cause severe, whole-body allergic reaction, heart rate disorders, and liver toxicity [37]. But, as with interactions, a greater research is needed [34]. Therefore, in case of not having information from international sanitary authorities in terms of interactions and adverse effects, it should be indicated on the labeling about this situation.
Another test done was related with the organoleptic characteristics. In three of the evaluated batches the presence of a characteristic color was found when the tisanes raw material was rubbed, as well as the observation of a grayish green color in it and a soft texture (which could be appreciated despite being quite crushed), as indicated by the BP [24]. Though, the batch 2 showed a browner color than the others, which can be explained by the foreign matters presence, as will be shown later. This is necessary because raw materials are often adulterated or substituted by other low-quality plant materials before harvesting, and during handling and storage [38]. Still, other tests such as the foreign matter determination are done to corroborate these results.

In Table-2, information regarding the branches and other foreign matter presence not related with the plant leaves is shown.

Table-2: Branches and foreign matter percentages in the analyzed batches of a boldo tisanes brand commercialized in Costa Rica.

\begin{tabular}{|l|l|l|l|l|l|}
\hline Batch & $\begin{array}{l}\text { Total sample } \\
\text { weight } \\
\text { g }\end{array}$ & $\begin{array}{l}\text { Branches } \\
\text { weight } \\
\text { g }\end{array}$ & $\begin{array}{l}\text { Branches } \\
\text { percentaje } \\
\mathbf{\%}\end{array}$ & $\begin{array}{l}\text { Foreign } \\
\text { matter weight } \\
\text { g }\end{array}$ & $\begin{array}{l}\text { Foreign matter } \\
\text { percentage } \\
\text { \% }\end{array}$ \\
\hline $\mathbf{1}$ & 10.6041 & 0.3844 & 4 & 0.0046 & 0 \\
\hline $\mathbf{2}$ & 12.1958 & 1.2323 & 10 & 0.0545 & 0 \\
\hline $\mathbf{3}$ & 14.0338 & 0.5925 & 4 & 0.0791 & 1 \\
\hline $\mathbf{4}$ & 11.2267 & 0.1626 & 1 & 0.0123 & 0 \\
\hline
\end{tabular}

The batch 2 does not comply with the requested specification of the $\mathrm{BP}$ for the maximum branches percentage in the sample, being this higher than the $4 \%$ established [24]. This information is worrisome, because it indicates that the product is not constituted by the plant part required to exert the pharmacological effect [34]. It is an adulteration example, since there is a partial substitution of the crude drug with inferior commercial varieties which may not have any therapeutic potential as that of the original drug [39]. Therefore, this can cause that the expected therapeutic effect is not achieved. Hence, it is necessary for the company to have a greater control of the raw material prior to the tisanes filling. As opposed, the four batches do meet the foreign matter percentage. These components include soil, stone, sand, dust, glass, metal, plastic, mold, insects, and animal excreta [40].

As for the minimum fill test, this was done to determine if the tisanes content met the limit established by the USP [25]. Table-3 shows all the results obtained.

Table-3: Labeling percentage of the analyzed samples of each one of the batches of a boldo tisanes brand commercialized in Costa Rica

\begin{tabular}{|c|c|c|c|c|c|c|c|c|}
\hline \multirow[t]{3}{*}{ Tisane } & \multicolumn{8}{|l|}{ Batch } \\
\hline & \multicolumn{2}{|l|}{1} & \multicolumn{2}{|l|}{2} & \multicolumn{2}{|l|}{3} & \multicolumn{2}{|l|}{4} \\
\hline & $\begin{array}{l}\text { Weight } \\
\text { g }\end{array}$ & $\begin{array}{l}\text { Labeling } \\
\text { percentage } \\
\%\end{array}$ & $\begin{array}{l}\text { Weight } \\
\text { g }\end{array}$ & $\begin{array}{l}\text { Labeling } \\
\text { percentage } \\
\%\end{array}$ & $\begin{array}{l}\text { Weight } \\
\text { g }\end{array}$ & $\begin{array}{l}\text { Labeling } \\
\text { percentage } \\
\%\end{array}$ & $\begin{array}{l}\text { Weight } \\
\text { g }\end{array}$ & $\begin{array}{l}\text { Labeling } \\
\text { percentage } \\
\%\end{array}$ \\
\hline 1 & 1.0505 & 96 & 1.1102 & 101 & 1.2645 & 115 & 1.0701 & 97 \\
\hline 2 & 1.0871 & 99 & 1.1147 & 101 & 1.2394 & 113 & 1.1293 & 103 \\
\hline 3 & 1.0961 & 100 & 1.1405 & 104 & 1.2601 & 115 & 1.2233 & 111 \\
\hline 4 & 1.0776 & 98 & 1.1433 & 104 & 1.2943 & 118 & 1.1045 & 100 \\
\hline 5 & 1.0446 & 95 & 1.1136 & 101 & 1.3051 & 119 & 1.1184 & 102 \\
\hline 6 & 1.0232 & 93 & 1.0823 & 98 & 1.3026 & 118 & 1.1604 & 105 \\
\hline 7 & 1.0628 & 97 & 1.1047 & 100 & 1.2427 & 113 & 1.1358 & 103 \\
\hline 8 & 1.0756 & 98 & 1.0957 & 100 & 1.3032 & 118 & 1.1160 & 101 \\
\hline 9 & 1.0560 & 96 & 1.1172 & 102 & 1.2871 & 117 & 1.0840 & 99 \\
\hline 10 & 1.0316 & 94 & 1.1294 & 103 & 1.2868 & 117 & 1.0849 & 99 \\
\hline Mean value & 1.0605 & 96 & 1.1206 & 102 & 1.2786 & 116 & 1.1227 & 102 \\
\hline
\end{tabular}


For the minimum fill test, the four analyzed batches were in accordance with the stipulation of USP 40 [25]. Although the RTCA indicates that this test should only be done by sanitary surveillance or by received complaints [22], it is important because a large variation in the filling percentage could be reflected in adverse effects on the population that consumes the product.

Through the research carried out, the variations between the batches of Peumus boldus 1, 2, and 4 were within a range between 90 and $110 \%$ (except for a tisane of batch 4 ), indicating an adequate filling control. However, in batch 3 all the tisanes were above $110 \%$ (between 113 and 119\%), something that must be corrected. The concern about these values is due to the fact that the recommended dose is 1 to $2 \mathrm{~g}$ of the herbal product 2 to 3 times a day [34]. Ingesting a greater amount can cause a dose higher than the therapeutic range established for it (dosage range, or blood plasma or serum concentration usually expected to achieve the desired therapeutic effect) [41]. This can cause the side effects appearance [42].

Other assays were lead and arsenic limit tests. There are several case reports and studies that had documented that herbal medication may contain toxic ingredients, including heavy metals such as lead, mercury, and arsenic [43]. Its continuous exposure can cause degenerative diseases in the skeletal and nervous systems. Their alteration can be related to different conditions such as multiple sclerosis, Parkinson's disease, muscular dystrophy, Alzheimer's disease, and different cancer types [44]. The metal residues presence in the herbal plants is prevalent, since they are easily contaminated during growth, development, and processing [45]. In the case of lead, depending on the exposure level, it can originate neurological, hepatic, renal, hematological, circulatory, immunological, reproductive, developmental, auditory, gastrointestinal, and cardiovascular pathologies [46]. For the four studied batches, the results showed that the stain obtained for each of them generated a brown color of less intensity than the standard, as established by the European Pharmacopoeia [26].

In relation to the arsenic limit test, it was also in compliance with the specification indicated by the European Pharmacopoeia [26] for the four batches, as it was observed that each sample exhibited a less stain. This metal also represents a danger to humans. Arsenic found in water is almost entirely in the inorganic form and can be stable as both arsenite $\left(\mathrm{As}_{2} \mathrm{O}_{3}\right)$ and arsenate $\left(\mathrm{As}_{2} \mathrm{O}_{5}\right)$ [47]. Trivalent species $\left(\mathrm{As}^{3+}\right)$ are more toxic than pentavalent species $\left(\mathrm{As}^{5+}\right)$ [48]. Arsenic toxicity inactivates up to 200 enzymes, like those involved in cellular energy pathways, and DNA replication and repair. Unbound arsenic also exerts its toxicity by generating reactive oxygen intermediates during its redox cycling and metabolic activation processes that cause lipid peroxidation and DNA damage. Besides, $\mathrm{As}^{3+}$ binds thiol or sulfhydryl groups in tissue proteins of the liver, lungs, kidney, spleen, gastrointestinal mucosa, and keratin-rich tissues (skin, hair, and nails) [49]. The chronic toxicity associated generates skin (pigmentation and keratosis) and systemic manifestations (respiratory, gastrointestinal, liver, cardiovascular, and nervous system diseases, hematological effects, diabetes, and different cancer types) [50].

Another assay was the loss on drying one. The medicinal plant drying has enough potential to reduce the post harvest losses and to prevent product spoilage in storage [51]. This spoilage is caused by contaminating microorganisms and their toxins that may lead to diseases, making them hazardous for comsumption [52]. The information regarding this test is shown in Table 4.

Table-4: Loss on drying percentage of the different evaluated batches of a boldo tisanes brand commercialized in Costa Rica

\begin{tabular}{|l|l|l|l|}
\hline Batch & Initial weight $(\mathbf{g})$ & Final weight $(\mathbf{g})$ & Loss on drying percentage (\%) \\
\hline $\mathbf{1}$ & 1.2373 & 1.1135 & 10.0 \\
\hline $\mathbf{2}$ & 1.2294 & 1.1079 & 9.9 \\
\hline $\mathbf{3}$ & 1.1125 & 0.9972 & 10.4 \\
\hline $\mathbf{4}$ & 1.1077 & 0.9981 & 9.9 \\
\hline
\end{tabular}

In the case of the evaluated batches, the four have values that range from 9.9 to $10.4 \%$. The official literature consulted does not indicate a specific loss on drying percentage to the product made from boldo leaf. Yet, when analyzing the data, it is possible to observe that there is homogeneity in the drying process selected by the manufacturer. The importance of this characteristic is due to the fact that the drying process decreased the plant moisture content, aimed at preventing enzymatic and microbial activity, and consequently, preserving the product for extended shelf life. Also, an adequate process is needed to provide a rapid reduction in the moisture content without affecting the active ingredients quality [53].

As a complement, the total ash amount was determined for the 4 batches of Peumus boldus. This information is summarized in Table-5. 
Table-5: Total ash percentages of the different evaluated batches of a boldo tisanes brand commercialized in Costa Rica

\begin{tabular}{|l|l|l|l|}
\hline Batch & Initial weight $\mathbf{( g )}$ & $\begin{array}{l}\text { Total ash weight } \\
(\mathbf{g})\end{array}$ & Total ash percentage $(\boldsymbol{\%})$ \\
\hline $\mathbf{1}$ & 2.3319 & 0.2213 & 9.5 \\
\hline $\mathbf{2}$ & 2.5306 & 0.2535 & 10.0 \\
\hline $\mathbf{3}$ & 2.3615 & 0.2171 & 9.2 \\
\hline $\mathbf{4}$ & 2.2914 & 0.2134 & 9.3 \\
\hline
\end{tabular}

These batches showed compliance with the specification established for this required quality criteria, which is less than $13.0 \%$, according to USP 40 [25]. The residue remaining after plant material incineration represents both physiological and nonphysiological ash. Physiological ash is derived from plant tissues due to biochemical processes, while nonphysiological one consists of extraneous matter residue (sand, soil) deliberately or non-deliberately adhering to plant samples itself $[54,55]$. Therefore, the total ash test is another way to check the purity and/or the natural products adulteration $[56,57]$.

Finally, a series of microbiological tests were executed. The microbiological contamination control is important, because microorganisms may contaminate the finished product as well as the manufacturing plant. They can be the origin of certain diseases or may cause products spoilage [58], and can appear because of the cultivation and collection methods used, an inappropriate harvesting and cleaning, an unsuitable transportation, a prolonged drying and storage, a poor producers' hygiene, and the prevailing climate conditions related with the raw materials employed [59]. The microbial counts of both mesophilic microorganisms, and yeasts and molds showed values below those established by the RTCA [22] for the four studied batches.

Likewise, for these batches the presence of $E$. coli was not found. The absence of this pathogen must be assured, because although most $E$. coli strains live harmlessly in the colon and seldom cause disease in healthy individuals, a number of pathogenic strains can cause intestinal and extraintestinal diseases both on healthy and immunocompromised individuals [60]. In addition, its presence is an indicative of fecal contamination [61].

The absence of another pathogenic microorganism such as Salmonella sp was determined in the four sampled batches. This is considered the main cause of acute human bacterial gastroenteritis worldwide, being Salmonella enteritidis and Salmonella typhimurium the most frequently reported serovars [62]. Salmonella serotypes are associated with three distinct human disease syndromes, bacteremia, typhoid fever, and enterocolitis [63]. The RTCA indicates that this test should not be done for products that are prepared with boiling water [22]. But, in Costa Rica there is a tendency to use hot water, which is not an appropriate practice, given that some strains of Salmonella sp. are more resistant to heat [64].

\section{Conclusions}

The four analyzed batches of boldo tisanes were in compliance with the specifications of official books used for the following tests: minimum fill, lead limit, arsenic limit, loss on drying, total ash, microbial enumeration, and E. coli and Salmonella sp absence.

However, they did not were in compliance with the labeling test, given that only 2 of the 4 items established for the primary packaging (batch number and expiration date) and 3 of the 19 items indicated for the secondary packaging (qualitative-quantitative composition, interactions, and adverse effects) were not found. Another aspect was that the batch 2 had a browner color compared to the others, not complying with the specifications of the organoleptic test, specifically the color. This is reaffirmed by obtaining a greater percentage of branches in its composition during the foreign matter test. Finally, there is a recommendation regarding the need to improve the filling product process to avoid differences in the tisanes as large as those shown in this research. For these reasons, greater controls must be made on the raw material used for the product preparation to achieve reproducibility between the quality characteristics required for the different batches.

\section{ACKNOWLEDGEMENTS}

To the Laboratory of Pharmacognosy, the Laboratory of Phytopharmacology and Pharmaceutical and Cosmetic Technology (LAFITEC, for its Spanish acronym), the Laboratory of Pharmaceutical Products Analysis, and the Laboratory of Pharmaceutical Analysis and Assessment (LAYAFA, for its Spanish acronym) of the Universidad de Costa Rica, for allowing the use of different equipment and materials to carry out the investigation.

\section{REFERENCES}

1. Rabiei, Z. (2017). Anticonvulsant effects of medicinal plants with emphasis on mechanisms of action. Asian Pacific Journal of Tropical Biomedicine, 7(2), 166-172. 
2. Rakotoarivelo, N. H., Rakotoarivony, F., Ramarosandratana, A. V., Jeannoda, V. H., Kulman, A. R., Randrianasolo, A., \& Bussmann, R. W. (2015). Medicinal plants used to treat the most frequent diseases encountered in Ambalabe rural community, Eastern Madagascar. Journal of Etnobiology and Etnomedicine, 11(68).

3. Daniyal, M., \& Akram, M. (2015). Antifertility activity of medicinal plants. Journal of the Chinese Medical Association, 78, 382-388.

4. Chen, S. L., Yu, H., Luo, H. M., Wu, Q., Li, C. F., \& Steinmetz, A. (2016). Conservation and sustainable use of medicinal plants: problems, progress and prospects. Chinese Medicine, 11, 37.

5. Ozkan, G., Kamiloglu, S., Ozdal, T., Boyacioglu, D., \& Capanoglu, E. (2016). Potential Use of Turkish Medicinal Plants in the Treatment of Various Diseases. Molecules, 21(3).

6. Oblitas, G., Hernández-Córdoba, G., Chiclla, A., Antich-Barrientos, M., CcorihuamánCusitito, L., \& Romaní, F. (2013). Empleo de plantas medicinales en usuarios de dos hospitales referenciales del Cusco, Perú. Revista Peruana de Medicina Experimental y Salud Pública, 30(1), 64-68.

7. Sandasi, M., Chen, W., Vermaak, I., \& Viljoen, A. (2018). Non-destructive quality assessment of herbal tea blends using hyperspectral imaging. Phytochemistry Letters, 24, 94-101.

8. Liu, Y., Ahmed, S., \& Long, C. (2013). Etnobothanical survey of cooling herbal drinks from southern China. Journal of Ethnobiology and Ethnomedicine, 9(82).

9. Kara, D. (2009). Evaluation of trace metal concentrations in some herbs and herbal teas by principal component analysis. Food Chemistry, 114(1), 347-354.

10. Lasekan, O., \& Lasekan, A. (2012). Flavour chemistry of mate and some common herbal teas. Trends in Food Science \& Technology, 27(1), 37-46.

11. Pohl, P., Dzimitrowicz, A., Jedryczko, D., Szymczycha-Madeja, A., Welna, M., \& Jamroz, P. (2016). The determination of elements in herbal teas and medicinal plant formulations and their tisanes. Journal of Pharmaceutical and Biomedical Analysis, 130, 326-335.

12. Villar del Fresno, A. M., \& GómezSerranillos, P. (2006). Boldo. Farmacia Profesional, 20(4), 74-78.

13. Speisky, H., \& Cassels, B. K. (1994). Boldo and boldine: an emerging case of natural drug development. Pharmacological Research, 29(1), 1-12.

14. Ara Roldán, A. (2012). Cien plantas medicinales escogidas. Madrid: EDAF Antillas.

15. Bagué Serrano, A. J., \& Álvarez Cruz, N. S. (2012). Tecnología Farmacéutica. Alicante: Editorial Club Universitario.

16. García, J. E. (n.d.). La agricultura orgánica en Costa Rica. San José: Editorial Universidad Estatal a Distancia.

17. Debbie, S., Graeme, L., Pierre, D., Elizabeth, W., \& Kelvin, C. (2012). Pharmacovigilance of herbal medicine. Journal of Ethnopharmacology, 140(3), 513-518.

18. Carmona, F., \& Soares Pereira, A. M. (2013). Herbal medicines: old and new concepts, truths and misunderstandings. Revista Brasileira de Farmacognosia, 23(2), 379-385.

19. Mora Román, J. J., Alvarado Fernández, M. J., Apú Leitón, N., Arroyo Solórzano, J. D., Espeleta González, D., Piedra Navarro, H., \& Blanco Barrantes, J. (2018). Pruebas fisicoquímicas para la evaluación de la calidad de una marca costarricense de tisanas de valeriana. Revista Médica de la Universidad de Costa Rica, 12(1), 15-26.

20. Mora Román, J. J., Bermúdez Carvajal, K., Cordero Menéndez, Y., Hernández Vega, R., Porras León, D., Vargas González, R., ... Blanco Barrantes, J. (2018). Importance of the Quality Control of Herbal Teas: Evaluation of two Senna Leaf Tisanes Brands Commercialized in Costa Rica through Physicochemical and Microbiological Assays Stipulated in the Central American Technical Regulation 11.03.56.09. Scholars Academic Journal of Pharmacy, 7(8), 372-380.

21. Mora Román, J. J., Agüero Brenes, N., Angulo Morales, C., Castro Solís, J., Hidalgo Carrillo, G., van Hoof Gómez, M., ... Blanco Barrantes, J. (2018). Physicochemical and Microbiological Assays for Quality Evaluation of a Brand of Mentha piperita Tisanes in Costa Rica Market: Employment of the Central American Technical Regulation. Journal of Drug Delivery and Therapeutics, 8(5), 329337.

22. Consejo de Ministros de Integración Económica Centroamericana. (2011). RTCA 11.03.56.09 (Reglamento Técnico Centroamericano de Productos Farmacéuticos. Productos Naturales Medicinales para Uso Humano. Verificación de Calidad). Ciudad de Guatemala: Secretaría de Integración Económica Centroamericana.

23. Consejo de Ministros de Integración Económica Centroamericana. (2011). RTCA 11.04.41.06 (Reglamento Técnico 
Centroamericano. Productos farmacéuticos. Productos naturales medicinales para uso humano. Requisitos de etiquetado). Ciudad de Guatemala: Secretaría de Integración Económica Centroamericana.

24. British Pharmacopoeia Commission. (2014). British Pharmacopoeia 2015. London: The Stationery Office Limited on behalf of Medicines and Healthcare Products Regulatory Agency.

25. United States Pharmacopeia Convention. (2017). Pharmacopeia 40 and National Formulary 35. Maryland: United States Pharmacopeia Convention.

26. European Pharmacopoeia Commission. (2004). European Pharmacopoeia 5th ed. Strasbourg: Council of Europe.

27. Zao, Y. Y., Zhang, S. Q., Wei, F., Fan, Y. M., Sun, F., \& Bai, S. (2014). Quality Control of Natural Product Medicine and Nutrient Supplements 2014. Journal of Analytical Methods in Chemistry, 2014.

28. Veronin, M. (2011). Packaging and Labeling of Pharmaceutical Products Obtained from the Internet. Journal of Medical Internet Research, 13(1), e22.

29. Aung, M. M., \& Chang, Y. S. (2014). Traceability in a food supply chain: Safety and quality perspectives. Food Control, 39, 172184.

30. Ghaeli, P. (2014). Drugs Expiration Date Dilemma! Journal of Pharmaceutical Care, 2(1), 1-2.

31. Teixeira, C. C. C., Cabral, T. P. F., de Sousa, J. P. B., Teixeira, S. P., Bastos, J. K., \& de Freitas, L. A. P. (2016). Study of Quality Assurance For Peumus Boldus M Products By Botanic Profiling, Extraction Optimization, HPLC Quantification and Antioxidant Assay. Pharmacognosy Journal, 8(3), 264-272.

32. O’Brien, P., Carrasco-Pozo, C., \& Speisky, H. (2006). Boldine and its antioxidant or healthpromoting properties. Chemico-Biological Interactions, 159(1), 1-17.

33. Walstab, J., Wohlfarth, C., Hovius, R., Schmitteckert, S., Röth, R., Lasitschka, F., ... Niesler, B. (2014). Natural compounds boldine and menthol are antagonists of human 5-HT3 receptors: implications for treating gastrointestinal disorders. Neurogastroenterology \& Motility, 26, 810820.

34. Committee on Herbal Medicinal Reports. (2017). Assessment report on Peumus boldus Molina, folium. London: European Medicines Agency.

35. Boldo. (2020). In RxList. Retrieved January 15, 2020, from https://www.rxlist.com/boldo/supplements.htm \#Interactions

36. Boldo. (2020). In WebMD. Retrieved January 16, 2020, from https://www.webmd.com/vitamins/ai/ingredien tmono-593/boldo

37. Boldo (2020). In Drugs.com. Retrieved January $\quad 16, \quad 2020, \quad$ from https://www.drugs.com/npc/boldo.html

38. Fazal, H., Ahmad, N., \& Abbasi, B. H. (2013). Identification, Characterization, and Palynology of High-Valued Medicinal Plants. The Scientific World Journal, 2013.

39. Poornima, B. (2010). Adultration and Substitution in Herbal Drugs A Critical Anaysis. International Journal of Research in Ayurveda \& Pharmacy, 1(1), 8-12.

40. American Herbal Products Association. (2017). Guidance on Limits of Foreign Matter in Herbal Ingredients. Maryland: American Herbal Products Association.

41. Cooney, L., Loke, Y. K., Golder, S., Kirkham, J., Jorgensen, A., Sinha, I., \& Hawcutt, D. (2017). Overview of systematic reviews of therapeutic ranges: methodologies and recommendations for practice. BMC Medical Research Methodology, 17(84).

42. Kang, J. S., \& Lee, M. H. (2009). Overview of Therapeutic Drug Monitoring. The Korean Journal of Internal Medicine, 24(1), 1-10.

43. Sakharkar, P. (2017). Lead Poisoning Due to Herbal Medications. Indian Journal of Clinical Biochemistry, 32(4), 500-501.

44. Real, M. I. H., Azam, H. M., \& Majed, N. (2017). Consumption of heavy metal contaminated foods and associated risks in Bangladesh. Environmental Monitoring Assessment, 189(12), 651.

45. Mousavi, Z., Ziarati, P., Dehaghi, M. E., \& Qomi, M. (2014). Heavy Metals (Lead and Cadmium) in some Medicinal Herbal Products in Iranian Market. Iranian Journal of Toxicology, 8(24), 1004-1010.

46. Zhang, R., Wilson, V. L., Hou, A., \& Meng, G. (2015). Source of lead pollution, its influence on public health and the countermeasures. International Journal of Health, Animal Science and Food Safety, 2(1), 18-31.

47. Hughes, M. F., Beck, B. D., Chen Y., Lewis, A. S., \& Thomas D. J. (2011). Arsenic Exposure and Toxicology: A Historical Perspective. Toxicological Sciences, 123(2), 305-332.

48. Coryell, M., McAlpine, M., Pinkham, N. V., McDermott, T. R., \& Walk S. T. (2018). The gut microbiome is required for full protection against acute arsenic toxicity in mouse models. Nature Communications, 9(5424), 1-9. 
49. Ratnaike, R. N. (2003). Acute and chronic arsenic toxicity. Postgraduate Medical Journal, 79(933), 391-396.

50. Guha Mazumder, D. N. (2008). Chronic arsenic toxicity \& human health. The Indian Journal of Medical Research, 128(4), 436-447.

51. Fargali, H. M., Nafeh, A. E. A., Fahmy, F. H., \& Hassan, M. A. (2008). Medicinal herb drying using a photovoltaic array and a solar thermal system. Solar Energy, 82(12), 11541160.

52. Van Vuuren, S., Williams, V. L., Sooka, A., Burger, A., \& Van der Haar, L. (2014). Microbial contamination of traditional medicinal plants sold at the Faraday muthi market, Johannesburg, South Africa. South African Journal of Botany, 94, 95-100.

53. Rocha, R. P., Melo, E. C., \& Radünz L. L. (2011). Influence of drying process on the quality of medicinal plants: A review. Journal of Medicinal Plants Research, 5(33), 70767084.

54. Abdu, B. A., Adamu, U., Sani, S. M., \& Joshua, O. O. (2015). Physical and Phytochemicals Study Of Some Local Herbal Remedies. IOSR Journal of Pharmacy and Biological Sciences, 10(4), 5-10.

55. Monisha, S., \& Ragavan, B. (2015). Investigation of Phytochemical, Mineral Content, and Physiochemical Property of a Polyherbal Extract. Asian Journal of Pharmaceutical and Clinical Research, 8(3), 238-242.

56. Mehring, A. L. (1924). Total Ash Determination in Spices. Journal of Agricultural Research (Washington, D. C.), 29(11), 569-574.

57. Patil, D., \& Lokhande, R. (2017). The Study on Proximate Analysis of Ampelocissus Latifolia Root. International Journal of
Engineering Development and Research, 5(2), 1821-1823.

58. Karanam, V. R., Reddy, H. P., Raju, B. V. S., Rao, J. C., Kavikishore, P. B., \& Vijayalakshmi, M. (2008). Detection of indicator pathogens from pharmaceutical finished products and raw materials using multiplex PCR and comparison with conventional microbiological methods. Journal of Industrial Microbiology \& Biotechnology, 35, 1007-1018.

59. Amosu, A. M., Degun, A. M., \& Esan, E. B. (2014). Microbial contaminants in the herbal preparation from green pawpaw fruits. Biomedical Research, 25(4), 606-611.

60. Gomes, T. A. T., Elias, W. P., Scaletsky, I. C. A., Guth, B. E. C., Rodrigues, J. F., Piazza R. M. F., ... Martinez, M. B. (2016). Diarrheagenic Escherichia coli. Brazilian Journal of Microbiology, 47S, 3-30.

61. Al Kahtani, M. D. F. (2017). Identification and Quantification of Microbial Contaminations Present in Herbal Medicines Commonly Consumed by Women in Riyadh, Saudi Arabia. Journal of Agricultural Chemistry and Environment, 6, 83-92.

62. Zweifel, C., \& Stephan, R. (2012). Spices and herbs as source of Salmonella-related foodborne diseases. Food Research International, 45, 765-769.

63. Zhang, S., Kingsley, R. A., Santos, R. L., Andrews-Polymenis, H., Raffatellu, M., Figueiredo, J., ... Bäumler, A. J. (2003). Molecular Pathogenesis of Salmonella enterica Serotype Typhimurium-Induced Diarrhea. Infection and Immunity, 71(1), 1-12.

64. Doyle, M. E., \& Mazzotta, A. S. (2000). Review of Studies on the Thermal Resistance of Salmonellae. Journal of Food Protection, 63(6), 779-795. 